\title{
Entrepreneurial Orientation (EO) and Performance of Government-Linked Companies (GLCs)
}

\author{
Wei-Loon Koe*
}

\begin{abstract}
Quite often, people have negative views on government-linked companies (GLCS) due to the unsatisfactory performance of some key players. In order to improve the performance of GLCs in the country, Malaysian government implemented GLC Transformation Program (GLCT) in 2004. As the program is approaching its ending phase, some efforts are needed to assess the performance of GLCs. This study aimed to examine the influence of EO dimensions on the performance of GLCs. The sample of this study consisted of 153 subsidiaries and branches of G20. Based on the multiple regression analysis performed, this study found that all the five dimensions in EO, namely innovativeness (INNO), pro-activeness (PROA), risk-taking (RISK), competitive aggressiveness (COMP) and autonomy (AUTO) recorded significant positive effects on performance of GLCS. Competitive aggressiveness was identified as the most important factor that influences the performance of GLCS. As such, all the hypotheses developed for this study were supported. The results suggested that EO is not only suitable to be applied in privately owned companies, but also in GLCS. Hence, GLCs should not be perceived as public entities and they should be more entrepreneurial in managing their organizations to achieve high performance. Furthermore, this study also verified that EO is a good determinant of GLCs' performance. At the end of this paper, recommendations for future research have been put forth.
\end{abstract}

Keywords: entrepreneurial orientation (EO), firms, governmental-linked companies (GLCS), performance.

\section{Introduction}

Government-linked companies (GLCs) can be considered as an important driver of national development. In Malaysia, they account for $54 \%$ of capital market in Kuala Lumpur composite index, hire about 5\% of the workforce, provide strategic utilities and services to the public, execute the country's industrial policy, establish international linkages and most importantly develop the Bumiputera community (PCG Secretariat, 2005). However, due to the poor performances of some key players such as Malaysia Airline System

\footnotetext{
* Wei-Loon Koe, PhD Student, Universiti Teknologi MARA, 40450 Shah Alam, Selangor Darul Ehsan Malaysia, koeweiloon@yahoo.com.
} 
(MAS) and Proton Holdings, they usually give people negative impressions (Lau and Tong, 2008). Quite often, general public perceives them as bureaucratic, unprofitable, high in debts, low in returns and requiring multiple assistance from the government.

Knowing the importance of GLCs and the unsatisfactory performance of certain major players, government has initiated several strategies to improve the conditions. One of them is the unveiled GLC Transformation Program (GLCT), a program which aims to transform GLCs into high-performing organizations by 2015. The program was initiated by Malaysian former Prime Minister Tun Abdullah Ahmad Badawi in 2004. It is worth to highlight that one of the underlying principles of GLCT is "performance focus". Specifically, to achieve the objectives of this program, Malaysian Directors Academy (MINDA) was established to equip the top management of GLCs with worldclass knowledge and skills for performance improvement. As the program is approaching the final phase of its 10-year journey, it is practical to examine the performance of GLCs to see whether or not the program is fruitful. Moreover, improving the performance of GLCs is a critical step in realizing the vision for competitiveness and prosperity of our nation (Najid and Rahman, 2011).

Apparently, in order for GLCs to be at par with their counterparts in the private sectors, GLCs are required to change from being bureaucratic to being entrepreneurial. Entrepreneurial orientation (EO) has been considered as a major contributor to firms' performance. Quite a number of specialist literature such as Soininen et al. (2012a), Chen et al. (2012); Grande et al. (2011), Hameed and Ali (2011), Hafeez et al. (2011), Fairoz et al. (2010), Madsen (2007), Ripollés-Meliá et al. (2007) and Wiklund and Shepherd (2005) have found that dimensions in EO, namely innovativeness, proactiveness and risk-taking had significant influence on performance of firms. It can be said that majority of studies on EO-performance relationship are concentrating on the three aspects of EO mentioned above; the other two, i.e.: competitive aggressiveness and autonomy, have hardly been researched in the literature. This has yielded a lacuna in the literature.

As mentioned earlier, EO has been found as a factor affecting the performance of firms. However, studies which examine the relationship between EO and firms' performance are primarily using private firms or small and medium enterprises (SMEs) as the benchmark (Soininen et al., 2012a, 2012b; Hameed and Ali, 2011; Huang and Wang, 2011; Javalgi and Todd, 2011; Avlonitis and Salavou, 2007; Keh et al., 2007; Tzokas et al., 2001; just to name a few). In addition, most of the studies which examined the performance of GLCs are associated with the effects of firm's ownership (for examples, Najid and Rahman, 2011; Boubakri et al., 2009; Razak et al., 2008, 
2011; Ang and Ding, 2006; Sun et al., 2002). To date, there is a paucity of studies concentrating on the influence of EO towards performance of GLCs.

To add to the above, quite a number of existing literatures on performance of GLCs are qualitative studies; for instance, Norhayati and Siti-Nabiha (2009) have used case study in their studies. Moreover, a recent study by Omar et al. (2012) which concentrated on the effects of EO on GLCs' performance is qualitatively performed as well. It can be said that to date there is a lack of quantitative empirical research focusing on GLCs performance which specifically associated to EO.

Considering the above mentioned gaps, question such as "are dimensions in EO influence the performance of GLCs?" still remain unanswered. Therefore, this study is carried out with the aim to examine the influence of dimensions in EO, such as innovativeness, pro-activeness, risk-taking, competitive aggressiveness and autonomy on the performance of GLCs. The next section of this paper provides the literature review, research framework and hypotheses. It is then followed by discussions on research methodology. Findings will be presented in the subsequent section and the paper ends with conclusion and recommendations.

\section{Literature review}

\section{Government-linked Companies (GLCs) in Malaysia}

The term government-linked companies (GLCs) or state-owned enterprises (SOEs) or public enterprises has been used interchangeably. Lau and Tong (2008) described GLCs as companies which are controlled by government through government-linked investment companies (GLICs), the investment arms of the government. By doing so, the government has control over the appointment of board members and senior management as well as to make major decisions such as strategic, investment and restructuring. Although GLCs are profit orientated, they are also socially and environmentally responsible (Omar et al., 2012).

Without doubt, GLCs play a significant role in the development of a country. For instance, according to a report released by PCG Secretariat (2005), Malaysian GLCs account for $54 \%$ of capital market in Kuala Lumpur composite index and they employed about $5 \%$ of workforce in the country. They are also the major providers of public utilities and services such as transportation, water, power and telecommunication. Moreover, they are important in executing national industrial policy such as national car project, building up international linkages through foreign investments and joint ventures and lastly develop the Bumiputera community. 
However, the performance of GLCs is still far from satisfactory. For long, GLCs have been labeled as underperformed, bureaucratic, monopolists, practicing favoritism, politically influenced or even pet government projects (The Economist, 2008). Researchers have also concluded that state-owned enterprises are less profitable and less efficient than privatized enterprises (Boubakri et al., 2009; Ramasamy et al., 2005). In the local setting, Razak et al. (2011) have found that the financial performance of GLCs were not comparable to non-GLCs.

Thus, some reforms of these companies are really needed to change the people's perceptions and also to harvest from the investment made by the people's money. As such, a 10-year program called GLC Transformation Program (GLCT) was launched in 2004, with the main aim to transform the GLCs into high performing organizations by 2015 . Subsequently, the Putrajaya Committee on GLC High Performance (PCG), chaired by the Prime Minister and joined as members by heads of GLICs, was formed in 2005 to implement and oversee the initiatives executed in the program. As a result, 20 large GLCs controlled by GLICs were identified as G20 and were deemed as the focus of GLCT.

The transformation of GLCs is important because it is closely linked to Government Economic Transformation Program (ETP). As Najid and Rahman (2011) mentioned, improving the GLCs' performance is important in achieving our nations' vision for competitiveness and prosperity. Currently, GLCT is at its fourth or final phase. The latest GLCT progress report released by PCG in 2011 unfolded that GLCs are continuing on a growth path, with a remarkable 49\% increased in growth in 2010 and have become stronger than before. Their other achievements include regionalization of business, improved capabilities, increased resilience, improved market perception, developed social and economic values etc. The impressive results achieved by GLCs in recent years could be caused by the successful implementation of GLCT. It could also caused by the entrepreneurial qualities exhibited by them. Since studies have not been extensively conducted to confirm this relationship, this study was performed.

\section{Entrepreneurial Orientation (EO) and performance of firms}

Entrepreneurial orientation (EO) has been described by Lumpkin and Dess (1996: 136) as 'processes, practices, and decision-making activities that lead to new entry', and 'involves the intentions and actions of key players functioning in a dynamic generative process aimed at new-venture creation'. They further pointed out that the concept was comparable to entrepreneurial management (EM) by Stevenson and Jarillo (1990) and the dimensions associated to it were originated from Miller's (1983) conceptualization. 
EO has evolved from having three dimensions, namely: (i) innovativeness; (ii) risk taking and; (iii) pro-activeness (Covin and Slevin 1989, 1991) to five, with the other two known as competitive aggressiveness and autonomy (Lumpkin and Dess 1996).

For years, extensive studies have shown a significant influence of EO on performance of firms (Grande et al., 2011; Hafeez et al., 2011; Wiklund and Shepherd 2005; Covin and Slevin 1989). Specifically, Li et al. (2009) and Ripollés-Meliá et al. (2007) have confirmed the influence of EO in listed firms and established international firms respectively. As for companies of other sizes, EO has been found as a positive and relevant contributor to increase performance among small firms (Chandrakumara et al., 2011; Keh et al., 2007). Furthermore, it has also been confirmed by many previous results as a critical element to the success of small firms (Tzokas et al., 2001); for examples international expansion (Javalgi and Todd, 2011), financial performance (Hameed and Ali, 2011), sales growth (Casillas and Moreno, 2010) and employment growth (Madsen, 2007) of SMEs. In the local setting, Zainol and Daud (2011) have found that EO did have a significant influence on performance of business firms in Malaysia.

Interestingly, some contradicting results have been obtained in studies performed by Soininen et al. (2012a), in which they found EO as an individual construct did not positively relate to profitability. Their paper did show a positive influence of EO on growth, although such relationship was not confirmed by Arbaugh et al. (2009). Such a mixed result has indicated the need to re-examine the EO-performance relationship in business firms. One important insight from the above studies is that the way performance is assessed would have an impact on the EO-performance relationship. Since firms' performance can be determined through measuring the firms' sales growth, market share, profitability, stakeholder satisfaction or even overall performance (Lumpkin and Dess, 1996); firms' performance measurement should be given high attention.

From the above discussion, the influence of EO on performance of firms in the private sector has been extensively performed. Unfortunately, the effort to extend this EO-performance relationship on GLCs is still low. As such, this study was conducted to shed lights on such issue. Although there were some researchers who deemed EO as a unique construct (Grande et al., 2011; Hafeez et al., 2011; Wiklund, 1999), Lumpkin and Dess (1996) have urged to view it as a multidimensional construct because the dimensions of EO may vary independently subject to the context of environment and organization. Following Casillas and Moreno (2010), Hughes and Morgan (2007) and Li et al. (2009), this study regarded EO as having multiple dimensions, which consisted of (i) innovativeness; (ii) pro-activeness; (iii) risk taking; (iv) 
competitive aggressiveness and; ( $v$ ) autonomy. The discussions below further explain the effects of these five dimensions on the performance of firms. Research framework and hypotheses are presented in the following sections as well.

\section{Research framework and hypotheses}

\section{Innovativeness}

Innovativeness is closely related to Schumpeterian "process of creative destruction". According to Lumpkin and Dess (1996: 142), it "reflects a firm's tendency to engage in and support new ideas, novelty, experimentation, and creative processes that may result in new products, services, or technological processes." Regardless the market instability, firms were required to sustain a continuous state of innovativeness because innovation played an important part in determining the performance and success of firms (Hult et al., 2004). Firms which practiced innovative behavior were found to have higher performance (Awang et al., 2009). Indeed, innovativeness has been proven positively related to financial performance (Soininen, 2012b; Hameed and Ali, 2011), market share growth (Fairoz et al., 2010) and product performance (Hughes and Morgan, 2007) of firms. Similarly, Casillas and Moreno (2010) concluded higher growth rate of firms could be generated through more innovative practices in firms. As for non-private-owned sectors, innovation as a result from knowledge management initiatives did bring better organizational performance among GLCs (Rahman and Shariff, 2009). All the studies above have unanimously agreed that innovativeness positively affects performance and firms. Such consensus has led to the following hypothesis:

$\mathrm{H} 1$ : There is a positive relationship between innovativeness and performance of GLCs.

\section{Proactiveness}

Pro-activeness suggests "a forward-looking perspective that is accompanied by innovative or new-venturing activity" (Lumpkin and Dess, 1996: 146). Firms which possessed this quality were able to look for new business opportunities for the reason of improving their financial performance during recession (Soininen, 2012b). Casillas and Moreno (2010) indicated that higher proactiveness promotes higher growth rate in sales, simply because firms are more aggressive in searching and capturing business opportunities. True, Fairoz et al. (2010) also found that market share growth was significantly affected by proactiveness. This dimension which is characterized by willingness to take high-risk actions is also a vital contributor to new product performance (Avlonitis and Salavou, 2007). In addition, Hughes and Morgan 
(2007) confirmed a significant correlation between proactiveness product performance and customer performance among young high-technological firms. As comparable to the previous dimension, the proactivenessperformance relationship has reached a consensus among the previous researchers. Therefore, the hypothesis was developed as follow:

$\mathrm{H} 2$ : There is a positive relationship between proactiveness and performance of GLCs.

\section{Risk-taking}

Assuming risk has been regarded as a quality which is very related to entrepreneurship. Risk-taking, as delineated by Lumpkin and Dess (1996: 144), includes behavior such as "incurring heavy debt or making large resource commitments, in the interest of obtaining high returns by seizing opportunities in the marketplace. Risks and returns are inseparable. For instance, Soininen et al. (2012a) concluded that the higher the risk-taking orientation the higher the firms' profitability. Similarly, Hameed and Ali (2011) also found a direct and distinct effect of this EO dimension on firms' financial performance. Meanwhile, Fairoz et al. (2010) recorded a positive significant relationship between it and market share growth. On the contrary, Casillas and Moreno (2010) did not confirm that risk-taking positively influence growth. Hughes and Morgan (2007) also found no correlation between risktaking and performance. During economic downturn, risk-taking was found not able to guarantee financial performance of firms (Soininen et al., 2012b). Interestingly, this dimension was found to have a " $U$ "-shaped curvilinear relationship with firms' performance, which showed that high-risk taking firms could outperform the moderate-risk taking firms (Awang et al., 2009). Due to the inconsistencies of findings in existing studies, it indicated that influence of risk-taking on performance of firms required a re-examination. As such, the hypothesis below was constructed:

$\mathrm{H} 3$ : There is a positive relationship between risk-taking and performance of GLCs.

\section{Competitive aggressiveness}

Competitive aggressiveness refers to "a firm's propensity to directly and intensely challenge its competitors to achieve entry or improve position, that is, to outperform industry rivals in the marketplace" (Lumpkin and Dess, 1996: 148). It is believed that firms which are aggressive are able to compete with their rivals in the industry and sustain their business. Researchers who have included this dimension in their EO construct have confirmed its impact on firms' innovation performance (Madhoushi et al., 2011). On the contrary, Casillas and Moreno (2010) found no relationship between competitive 
aggressiveness and growth due to the dual-condition, both active and passive competitive aggressiveness. Similar result was also obtained in Hughes and Morgan (2007). The contradicting results indicated the need to re-study the effects of competitive aggressiveness on firms' performance. Hence, the hypothesis was suggested as below:

$\mathrm{H} 4$ : There is a positive relationship between competitive aggressiveness and performance of GLCs.

\section{Autonomy}

Lumpkin and Dess (1996: 140) explained autonomy as "independent action of an individual or a team in bringing forth an idea or a vision and carrying it through to completion." The significant positive relationship between autonomy and firms performance has been confirmed by Awang et al. (2009). However, such relationship was not proven by Casillas and Moreno (2010) and Hughes and Morgan (2007). The mixed results obtained by the previous researchers showed the need to investigate the relationship between autonomy and firms' performance. Thus, the following hypothesis was suggested:

H5: There is a positive relationship between autonomy and performance of GLCs.

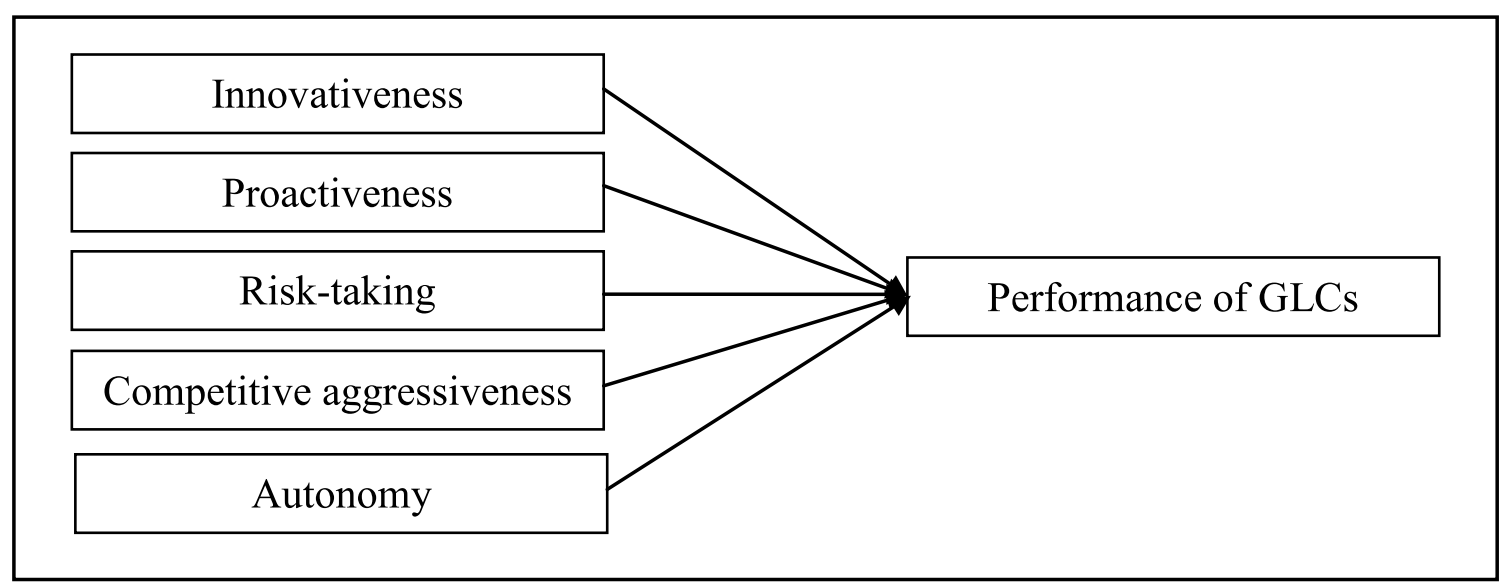

Figure 1. Research framework

\section{Methodology}

\section{Population and sample}

The sample of this study comprised of subsidiaries, including their branches of G20. The selected GLCs were represented by their respective topmanagement such as chief executive officer (CEO), general manager or senior 
executive. It is important to note that G20 refers to GLCs which are controlled by the five main GLICs, they are Khazanah Nasional Berhad (KNB), Permodalan Nasional Berhad (PNB), Lembaga Tabung Angkatan Tentera (LTAT), Lembaga Tabung Haji (LTH) and Kumpulan Wang Simpanan Pekerja (KWSP). Although the name G20 is given, it actually consists of 19 GLCs due to strategic exercises such as mergers, demergers and corporate restructuring. a total of $250 \mathrm{GLCs}$ were selected as the sample. Of the 250 questionnaires sent, 167 were returned and 14 were unusable. Thus, the final sample comprised 153 GLCs. It indicated a response rate of $61.2 \%$. The response rate was considered high and acceptable, compared to studies sampled on private firms which was about 20\% to 30\% (Zainol and Daud, 2011; Li et al., 2009; Hughes and Morgan, 2007) or even just around 10\% (Casillas and Moreno, 2010).

\section{Research instrument and data collection}

As this study was quantitative in nature, questionnaire survey was regarded as appropriate. The instrument used in this study was a self-administered questionnaire. Items used by previous researchers were adapted in the questionnaire to ensure content validity of scale used. As the items originated in Western countries, slight modifications such as simplification of complex sentences have been performed to ascertain the items fit the context of Malaysia. All items were worded in English because the respondents were top executives of GLCs, they possessed high proficiency in English. In order to increase the response rate, the data collection was conducted through a three-step process. First, the researcher e-mailed the questionnaires to respondents which held valid e-mail addresses. For the rest, traditional mail method was used. Then, a first-reminder was sent to the respondents after one month and a second-reminder was sent to respondents one month after the first-reminder.

\section{Variables measurements}

All items for EO were adapted from Hughes and Morgan (2007), they covered the five dimensions of EO and gauged on five-point Likert scale ( 1 = "strongly disagree" to $5=$ "strongly agree"). a total of 18 items were developed to capture the EO dimensions of innovativeness (INNO - three items), proactiveness (PROA - three items), risk-taking (RISK - three items), competitive aggressiveness (COMP - three items) and autonomy (AUTO six items). Meanwhile, items for firm performance were adapted from Li et al. (2009), which assessed the performance (PERF) in regards to efficiency (three items), growth (three items) and profit (three items). All items used five-point Likert scale ranged from 1 = "strongly disagree" to 5 = "strongly agree." Efficiency was determined by respondents' satisfaction on return 
on investment (ROI), return on equity (ROE) and return on assets (ROA). Growth was assessed by respondents' satisfaction on sales growth, employee growth and market share growth. Profit was measured through respondents' satisfaction on return on sales, net profit margin and gross profit margin.

\section{Reliability and validity}

The stability or consistency of items measuring the variables, also known as reliability, can be determined through internal consistency (Sekaran and Bougie, 2009). Cronbach's alpha ( $\alpha$ ) is considered to be the most popular indicator of internal consistency, the $\alpha$-values of variables used in this study are shown in Table 1 . The $\alpha$-values of most variables were acceptable with $\alpha>0.7$ except for AUTO $(\alpha>0.8)$, which was preferable (Pallant, 2011). In comparison, the $\alpha$-values of INNO and COMP were slightly lower than Hughes and Morgan (2007); while the other two variables (PROA and RISK) had better internal consistency reliability than the previous researchers.

Table 1. Internal consistency reliability

\begin{tabular}{lcc}
\hline \multirow{2}{*}{ Variables } & \multicolumn{2}{c}{ Cronbach's Alpha $(\boldsymbol{\alpha})$} \\
\cline { 2 - 3 } & Current Study & Previous Study \\
\hline INNO & 0.71 & Hughes and Morgan $(2007)=0.81$ \\
PROA & 0.76 & Hughes and Morgan $(2007)=0.75$ \\
RISK & 0.79 & Hughes and Morgan $(2007)=0.77$ \\
COMP & 0.74 & Hughes and Morgan $(2007)=0.75$ \\
AUTO & 0.86 & Hughes and Morgan $(2007)=0.86$ \\
PERF & 0.71 & N/A \\
\hline
\end{tabular}

In order to ensure that the items were able to measure the desired variables, the questionnaire was validated by experts from both academics and industry sectors such as academicians and managers. Thus, face validity of the instrument was confirmed. As there were 153 sample cases in this study, conducting factor analysis to further validate the construct validity was deemed viable because it has exceeded the minimum requirement of 50 cases for factor analysis (Hair et al., 2006). Thus, exploratory factor analysis with principal components extraction and Varimax rotation was performed for both independent and dependent variables.

For EO, the Kaiser-Meyer-Olkin value was 0.61, exceeding the minimum threshold of 0.60 (Pallant, 2011). Moreover, Barlett's Test of Sphericity was significant as well (Approx. $\chi 2=1474.13 ; \mathrm{df}=300$ and Sig. $=0.00$ ). Both KMO and Barlett's statistics verified that factor analysis was appropriate to be conducted. The rule of Eigenvalue $>1.0$ was followed and only factors with factor loading $>0.5$ were retained for practical significance (Hair et al., 2006). 
Table 2 depicts the results of factor analysis for EO. Based on the results, it was found that all items for EO have been successfully loaded into five dimensions. The cumulative percentage of variance explained was $63.43 \%$, indicating that the factors were sufficient (Hair et al., 2006).

Table 2. Factor Analysis of EO

\begin{tabular}{|c|c|c|c|c|c|}
\hline \multirow{2}{*}{ Items } & \multicolumn{5}{|c|}{ Components } \\
\hline & 1 & 2 & 3 & 4 & 5 \\
\hline $\begin{array}{l}\text { Innovativeness (INNO) } \\
\text { Actively introduce improvements and } \\
\text { innovations } \\
\text { Seek out new ways of doing things } \\
\text { Creative in methods of operation }\end{array}$ & $\begin{array}{l}0.66 \\
0.60 \\
0.57\end{array}$ & & & & \\
\hline $\begin{array}{l}\text { Proactiveness (PROA) } \\
\text { Take initiatives in every situation } \\
\text { Initiate actions to which other organizations } \\
\text { respond } \\
\text { Excel at identifying opportunities }\end{array}$ & & $\begin{array}{l}0.79 \\
0.69 \\
0.58\end{array}$ & & & \\
\hline $\begin{array}{l}\text { Risk-taking (RISK) } \\
\text { "Risk-taker" is considered a positive attribute } \\
\text { Explore and experiment for opportunities } \\
\text { Take calculated risks with new ideas }\end{array}$ & & & $\begin{array}{l}0.73 \\
0.54 \\
0.52\end{array}$ & & \\
\hline $\begin{array}{l}\text { Competitive Aggressiveness (COMP) } \\
\text { The business is intensively competitive } \\
\text { Take bold or aggressive approach when } \\
\text { competing } \\
\text { Undo and out-maneuver the competition }\end{array}$ & & & & $\begin{array}{l}0.63 \\
0.60 \\
0.58\end{array}$ & \\
\hline $\begin{array}{l}\text { Autonomy (AUTO) } \\
\text { Freedom and independence in doing works } \\
\text { Make and instigate changes in performing jobs } \\
\text { Freedom to communicate without interference } \\
\text { Authority and responsibility to act alone } \\
\text { Act and think without interference } \\
\text { Access to all vital information }\end{array}$ & & & & & $\begin{array}{l}0.78 \\
0.77 \\
0.73 \\
0.60 \\
0.52 \\
0.51\end{array}$ \\
\hline Eigenvalues & 3.85 & 3.09 & 2.51 & 2.12 & 1.78 \\
\hline Cumulative Variance Explained (\%) & 17.41 & 31.78 & 43.83 & 54.30 & 63.43 \\
\hline
\end{tabular}

Table 3 illustrates the factor analysis of firm performance (PERF). The $\mathrm{KMO}$ measure of sampling adequacy obtained was 0.77 ; which has passed the lowest base of 0.6 (Pallant, 2011). Meanwhile, Barlett's Test of Sphericity was significant at $p$-value $=0.00$, approx. $\chi 2=351.73$ and $d f=25$. Again, the outcomes indicated the suitability of factors analysis for PERF. All the nine items with factor loading values $>0.5$ were successfully loaded into one factor. The cumulative percentage of variance explained was $64.98 \%$. 
Table 3. Factor Analysis of Performance (PERF)

\begin{tabular}{lc}
\hline & \\
Items & Component \\
\cline { 2 - 2 } & $\mathbf{1}$ \\
\hline Performance (PERF) & 0.85 \\
Satisfied with return on assets & 0.82 \\
Satisfied with return on equity & 0.77 \\
Satisfied with sale growth & 0.76 \\
Satisfied with employee growth & 0.75 \\
Satisfied with return on investment & 0.68 \\
Satisfied with market share growth & 0.63 \\
Satisfied with net profit margin & 0.59 \\
Satisfied with return on sales & 0.56 \\
Satisfied with gross profit margin & 4.52 \\
\hline Eigenvalues & 64.98 \\
Cumulative Variance Explained (\%) & \\
\hline
\end{tabular}

\section{Findings and discussions}

\section{Descriptive analysis}

The information of the characteristics of GLCs in this study is presented in Table 4. The results indicated that about one third of the GLCs were located in central region ( $N=52,34 \%)$, followed by southern region ( $N=35,23 \%)$, northern region ( $N=29,19 \%)$, east coast $(N=26,17 \%)$ and only $11 \mathrm{GLCs}(7 \%)$ were from East Malaysia. In terms of the types of industry, 63 GLCs (41\%) were in servicing, $47(31 \%)$ in manufacturing, $29(19 \%)$ in other types of industry and 14 (9\%) in agriculture. As far as their age was concerned, it was found that more than half of the GLCs were established more than 10 years ago $(11$ to 15 years $=41 \mathrm{GLCs}$ or $27 \%$ and more than 16 years ago $=64 \mathrm{GLCs}$ or $42 \%$ ). It was followed by GLCs which have existed for 6 to 10 years $(N=32$, $21 \%)$ and for less than 5 years $(N=16,11 \%)$.

Table 4. Characteristics of firms

\begin{tabular}{lcc}
\hline \multicolumn{1}{c}{ Characteristics } & \multicolumn{2}{c}{$\mathbf{N = 1 5 3}$} \\
\cline { 2 - 3 } & $\mathbf{F}$ & $\mathbf{2}$ \\
\hline Location & & \\
$\quad$ Northern Region - Perlis, Kedah, Pulau Pinang and Perak & & \\
Central Region - Kuala Lumpur, Putra Jaya, Selangor and Negeri & 29 & 18.95 \\
Sembilan & 52 & 33.99 \\
Southern Region - Melaka and Johor & 35 & 22.88 \\
East Coast - Pahang, Terengganu and Kelantan & 26 & 16.99 \\
East Malaysia - Sabah, Sarawak and Labuan & 11 & 7.18 \\
& & \\
\hline
\end{tabular}




\begin{tabular}{lcc} 
Type of Industry & & \\
Manufacturing & 47 & 30.72 \\
Servicing & 63 & 41.17 \\
Agriculture & 14 & 9.15 \\
Others & 29 & 18.95 \\
Years of Establishment & & \\
$<5$ years & 16 & 10.45 \\
$6-10$ years & 32 & 20.92 \\
$11-15$ years & 41 & 26.80 \\
$>16$ years & 64 & 41.83 \\
\hline
\end{tabular}

\section{Mean score and correlation analysis}

Table 5 summarizes the information on means and standard deviations (S.D.) of variables and correlations between variables. Generally, all the independent variables had mean values that ranged from 3.77 to 4.06 . INNO recorded the highest mean value at 4.06 (S.D. $=0.66$ ), while PROA noted the lowest mean at 3.77 (S.D. $=0.72$ ). The mean value for dependent variable, PERF was 4.31 with S.D. of 0.69 .

Correlation was conducted to identify the strength and direction of relationship between two variables (Pallant, 2011). As this study employed interval level variables, Pearson product-moment correlation coefficient $(r)$ was determined (Pallant, 2011; Cooksey, 2007). As explained by Elifson et al. (1998), the r-value should range from 0 (no relationship) to 1 (perfect relationship). They further suggested that $r$-value which ranged from 0.01 to 0.30 should be considered as weak, from 0.31 to 0.70 it should be regarded as moderate and from 0.71 to 0.99 it should be interpreted as strong. However, it is important to note that all the r-values obtained were less than 0.70 (highest $r=0.64$ ); as such, there was no problem of multicollinearity and all variables were retained (Pallant, 2011).

Results in Table 5 indicated that significant relationships ( $p$-value $<0.05$ ) existed between pairs of independent variables, except between INNO and PROA and RISK and AUTO. In terms of relationships between independent and dependent variables, all relationships were found to be statistically significant at $p$-value $<0.05$. In other words, INNO $(r=0.46, p<0.01)$, PROA $(r=0.18, p$ $<0.05)$, RISK $(r=0.55, p<0.01), \operatorname{COMP}(r=0.64, p<0.01)$ and AUTO $(r=0.33$, $p<0.01$ ) were found to be significantly and positively correlated to PERF. Based on the suggestion by Elifson et al. (1998), all strengths of relationships between PERF and EO dimensions were moderate, except for PROA which was weak. 
Table 5. Mean, standard deviation and Pearson correlation coefficient

\begin{tabular}{lcccccccc}
\hline & Mean & S.D. & INNO & PROA & RISK & COMP & AUTO & PERF \\
\hline INNO & 4.06 & 0.66 & 1 & & & & & \\
PROA & 3.77 & 0.72 & 0.23 & 1 & & & & \\
RISK & 3.94 & 0.72 & $0.36^{*}$ & $0.49^{* *}$ & 1 & & & \\
COMP & 4.02 & 0.62 & $0.37^{*}$ & $0.39^{* *}$ & $0.52^{* *}$ & 1 & & \\
AUTO & 3.82 & 0.77 & $0.24^{* *}$ & $0.46^{* *}$ & 0.32 & $0.31^{* *}$ & 1 & \\
PERF & 4.31 & 0.69 & $0.46^{* *}$ & $0.18^{*}$ & $0.55^{* *}$ & $0.64^{* *}$ & $0.33^{* *}$ & 1 \\
\hline
\end{tabular}

*. Correlation is significant at the 0.05 level (2-tailed).

**. Correlation is significant at the 0.01 level (2-tailed).

\section{Multiple regression analysis}

There were five hypotheses suggested in this study. In testing the hypotheses, multiple regression analysis was employed. Multiple regression analysis was considered as appropriate in this study because it hypothesized that more than one independent variable explained the variance in dependent variable (Sekaran and Bougie, 2009). Table 6 summarizes the results of analysis.

Table 6. Multiple Regression Analysis

\begin{tabular}{lccc}
\hline Independent Variables & $(\boldsymbol{\beta})$ & T-value & P-value \\
\hline COMP & 0.42 & 6.68 & 0.00 \\
RISK & 0.33 & 5.63 & 0.00 \\
INNO & 0.31 & 5.96 & 0.00 \\
AUTO & 0.19 & 3.48 & 0.00 \\
PROA & 0.11 & 2.03 & 0.04 \\
& & & \\
\hline $\mathbf{R}^{2}$ & 0.63 & & \\
Adjusted R & 0.62 & & 0.00 \\
F-value & 51.28 & & \\
\hline
\end{tabular}

Dependent Variable: PERF

The analysis revealed that data in this study fits the model well; it was confirmed by the F-statistics of 51.28 and significant at 0.00 . Thus, the relationship between EO and PERF was statistically significant. The R-square obtained was 0.63 and adjusted R-square was 0.62 . This indicated that $62 \%$ of change in firm performance was affected by EO while other factors accounted for the remaining $38 \%$. The output also showed that all the five dimensions in EO, in which COMP $(\beta=0.42, p<0.01)$, RISK $(\beta=0.33, p<0.01)$, INNO $(\beta=0.31, p<0.01)$, AUTO $(\beta=0.19, p<0.01)$ and PROA $(\beta=0.11, p<0.05)$ 
significantly and positively influenced the performance of GLCs. In addition, the most important EO dimension which affected the performance of GLCs was competitive aggressiveness (COMP). As for the hypotheses testing, the results further denoted that $\mathrm{H} 1$ to $\mathrm{H} 5$ were supported.

\section{Discussion}

From the statistical analyses performed, this study found that dimensions in EO significantly and positively influenced the performance of GLCs. In particular, competitive aggressiveness (COMP) was identified as the most important factor, which was in contrast to Casillas and Moreno (2010) Hughes and Morgan (2007). As mentioned by Lumpkin and Dess (1996), this dimension plays a vital role in ensuring the firm to outperform the other rivals in the industry. GLCs in Malaysia are not only facing competition from local privately-owned business firms, but also the international giants. In addition, the pressure from government through various governmental programs, such as GLCT, has also changed the competitive landscape of GLCs in the country. The competitive condition has definitely caused the GLCs to aggressively and intensely seek ways to sustain in the industry.

Risk-taking (RISK) emerged as the next most important EO dimension which influenced the performance of GLCs. The finding seemed to support Soininen et al. (2012a), Hameed and Ali (2011) and Fairoz et al. (2010), in which assuming risk is related to firms' performance. As we know, risks and returns are closely related to each other. GLCs are backed by government; it is therefore comparatively easy for them to obtain the necessary resources for making investment whenever they identified new opportunities. This has definitely resulted in bold and brave decisions in making investments by the top management of GLCs.

Innovativeness (INNO) has been evidenced by Soininen (2012b), Hameed and Ali (2011), Casillas and Moreno (2010), Fairoz et al. (2010), Awang et al. (2009), Hughes and Morgan (2007) and Hult et al. (2004) as an important determinant of firms' performance. Similar to the previous studies, this study also found such a result and further confirmed the findings by Rahman and Shariff (2009) in the context of GLCs. With the aim to develop an "innovation economy", Malaysian government has continuously urged organizations from both private and public sectors to be innovative. With the establishment of governmental agencies such as Ministry of Science, Technology and Innovation (MOSTI) and Malaysia Innovation Agency (AIM), various financial and non-financial resources have been given to stimulate innovation among firms. As such, there seems no reason why GLCs are not innovative. 
This study also found a significant relationship between autonomy (AUTO) and performance of GLCs. Although it was in contradiction with Casillas and Moreno (2010) and Hughes and Morgan (2007), it supported Awang et al. (2009). It is believed that the minimal interference from government and clear national vision have helped the top management of GLCs to steer their organizations well towards success. Lastly, similar to Soininen (2012b), Casillas and Moreno (2010), Fairoz et al. (2010), Avlonitis and Salavou (2007) and Hughes and Morgan (2007); proactiveness (PROA) was proven to significantly affect the performance of GLCs. This could be inferred by the increasing quality and ability of GLCs' top-management in being forward-looking and seeking new opportunities.

\section{Conclusion}

This study was performed with the aim to examine the influence of five dimensions in EO as conceptualized by Lumpkin and Dess (1996) on the performance of GLCs. It was found that about one third of GLCs in Malaysia were concentrated in the central region, majority of them were in manufacturing and servicing sectors and more than half of them were operating for more than 10 years. Statistical tests revealed that all the five dimensions in EO, namely innovativeness, pro-activeness, risk-taking, competitive aggressiveness and autonomy significantly and positively influenced the performance of GLCs. Competitive aggressiveness was identified as the most important factor influencing the performance of GLCs, followed by risk-taking, innovativeness, autonomy and proactiveness. Thus, all the hypotheses developed for this study were supported.

\section{Implications}

As mentioned by Lau and Tong (2008), people usually have negative views on GLCs. The negative image of GLCs is mainly caused by their inefficiencies and ineffectiveness in performance. This study has demonstrated that being entrepreneurial did affect the performance of GLCs. Therefore, GLCs should not perceive themselves as public entities although they are linked to government. Contrastively, they should regard themselves as entrepreneurs and practice entrepreneurial behavior. In particular, they have to be aggressive in competing with competitors, take the necessary initiatives and intensely seek for new opportunities are important ingredients to be highperformers. Being risk-taking, innovative, autonomous and proactive are other entrepreneurial qualities that GLCs should possess.

Theoretically, this study regarded EO as multidimensional instead of a unique complex construct. Thus, it shed lights on treating EO as having five multifaceted dimensions rather than three dimensions or simply a uniform 
construct because the dimensions of EO vary independently (Lumpkin and Dess, 1996). It has also showed that different dimensions possessed different strength of influence on performance of firms. As Hughes and Morgan (2007) mentioned, the relationship between EO and firms' performance is complex; thus, firms are required to pursue those dimensions that are deemed appropriate to improve their performance. Furthermore, it also proved that EO is not only suitable to be used in predicting performance in privatelyowned business firms, but also GLCs.

\section{Limitations and recommendations}

Of course, this study is not without any limitations. There is no doubt that EO exerts direct influence on GLCs performance. However, this relationship may be moderated or mediated by other environmental factors, for examples knowledge creation (Li et al., 2009), learning (Wang, 2008), managerial power (Davis et al., 2010) or even family involvement (Casillas and Moreno, 2010). As such, future researchers are suggested to integrate these constructs into the EO-performance studies, specifically to look at their moderating or mediating effects between EO and firms' performance. Furthermore, this study treated performance which was measured by efficiency, growth and profit as one single construct. Future studies could consider treating them separately and look at the influence of different dimensions of EO on these three types of performance. This paper also measured performance subjectively through the opinion of firm's top management. Future researchers could employ an objective method by analyzing the performance based on readily available data. Lastly, this study adopted a cross-sectional design. As performance may be affected by the economic and other business conditions at the time when data was collected, future research could consider a longitudinal design to see the effects of EO on performance over time.

\section{References}

Ang, J.S. and Ding, D.K. (2006). Government Ownership and the performance of government-linked companies: The case of Singapore. Journal of Multinational Financial Management, 16, 64-88.

Arbaugh, J.B., Cox, L.W., Camp, S.M. (2009). Is entrepreneurial orientation a global construct? a multi-country study of entrepreneurial orientation, growth strategy, and performance. The Journal of Business Inquiry, 8(1), 12-25.

Avlonitis, G.J., Salavou, H.E. (2007). Entrepreneurial orientation of SMEs, product innovativeness, and performance. Journal of Business Research, 60(5), 566-575.

Awang, A., Khalid, S.A., Yusof, A.A., Kassim, K.M., Ismail, M., Zain, R.S. and Madar, A.R.S. (2009). Entrepreneurial orientation and performance 
relations of Malaysian Bumiputera SMEs: The impact of some perceived environmental factors. International Journal of Business and Management, 4(9), 84-96.

Boubakri, N., Cosset, J.C., Guedhami, O. (2009). From state to private ownership: Issues from strategic industries. Journal of Banking and Finance, 33(2), 367-379.

Casillas, J.C., Moreno, A.M. (2010). The relationship between entrepreneurial orientation and growth: The moderating role of family involvement. Entrepreneurship \& Regional Development, 22(3-4), 265-291.

Chandrakumara, A., Zoysa, A.D., Manawaduge, A. (2011). Effects of the entrepreneurial and managerial orientations of owner-managers on company performance: An empirical test in Sri Lanka. International Journal of Management, 28(1), 139-158.

Chen, Y.C., Li, P.C., Evans, K.R. (2012). Effects of interaction and entrepreneurial orientation on organizational performance: Insights into market driven and market driving. Industrial Marketing Management, 41, 1019-1034.

Cooksey, R.W. (2007). Illustrating Statistical Procedures: For Business, Behavioral and Social Science Research. Australia: The Tilde Group.

Covin, J.G., Slevin, D.P. (1989). Strategic management of small firms in hostile and benign environments. Strategic Management Journal, 10, 75-87.

Covin, J.G., Slevin, D.P. (1991). a conceptual model of entrepreneurship as firm behavior. Entrepreneurship Theory and Practice, Fall, 7-25.

Davis, J.L., Bell, R.G., Payne, G.T., Kreiser, P.M. (2010). Entrepreneurial orientation and firm performance: The moderating role of managerial power. American Journal of Business, 25(2), 41-54.

Elifson, K.W., Runyon, R.P., Haber, A. (1998). Fundamental of Social Statistics. New York: McGraw Hill.

Fairoz, F.M., Hirobumi, T., Tanaka, Y. (2010). Entrepreneurial orientation and business performance of small and medium scale enterprises of Hambantota District Sri Lanka. Asian Social Science, 6(3), 34-46.

Grande, J., Madsen, E.L., Borch, O.J. (2011). The relationship between resources, entrepreneurial orientation and performance in farm-based ventures. Entrepreneurship \& Regional Development, 23(3-4), 89-111.

Hafeez, S., Chaudhry, R.M., Siddiqui, Z.U., Rehman, K.U. (2011). The effect of market and entrepreneurial orientation on firm performance. Information Management and Business Review, 3(6), 389-395.

Hair, J.F., Black, W.C., Babin, B.J., Anderson, R.E. and Tatham, R.L. (2006). Multivariate Data Analysis, (6th Ed). Upper Saddle River, NJ: Prentice Hall.

Hameed, I. and Ali, B. (2011). Impact of entrepreneurial orientation, entrepreneurial management and environmental dynamism on firm's financial performance. Journal of Economics and Behavioral Studies, 3(2), 101-114. 
Huang, S.K., Wang, Y.L. (2011). Entrepreneurial orientation, learning orientation, and innovation in small and medium enterprises. Procedia Social and Behavioral Sciences, 24, 563-570.

Hughes, M., Morgan, R.E. (2007). Deconstructing the relationship between entrepreneurial orientation and business performance at the embryonic stage of firm growth. Industrial Marketing Management, 36, 651-661.

Hult, G.T.M., Hurleyb, R.F., Knight, G.A. (2004). Innovativeness: Its antecedents and impact on business performance. Industrial Marketing Management, 33, 429-438.

Javalgi, R.G., Todd, P.R. (2011). Entrepreneurial orientation, management commitment, and human capital: The internationalization of SMEs in India. Journal of Business Research, 64(9), 1004-1010.

Keh, H.T., Nguyen, T.T.M., Ng, H.P. (2007). The effects of entrepreneurial orientation and marketing information on the performance of SMEs. Journal of Business Venturing, 22, 592-611.

Lau, Y.W., Tong, C.Q. (2008). Are Malaysian Government-Linked Companies (GLCs) creating values? International Applied Economics and Management Letters, 1(1), 9-12.

Li, Y.H., Huang, J.W., Tsai, M.T. (2009). Entrepreneurial orientation and firm performance: The role of knowledge creation process. Industrial Marketing Management, 38, 440-449.

Lumpkin, G.T., Dess, G.G. (1996). Clarifying the entrepreneurial orientation construct and linking it to performance. Academy of Management Review, 21(1), 135-172.

Madhoushi, M., Sadati, A., Delavari, H., Mehdivand, M., Mihandost, R. (2011). Etrepreneurial orientation and innovation performance: the mediating role of knowledge management. Asian Journal of Business Management, 3(4), 310-316.

Madsen, E.L. (2007). The significance of sustained entrepreneurial orientation on performance of firms - a longitudinal analysis. Entrepreneurship \& Regional Development, 19 (March), 185-204.

Miller, D. (1983). The correlates of entrepreneurship in three types of firms. Management Science, 29, 770-791.

Najid, N.A., Rahman, R.A. (2011). Government ownership and performance of Malaysian government-linked companies. International Research Journal of Financial and Economics, 61, 42-56.

Norhayati, M.A., Siti-Nabiha, A.K. (2009). a case study of the performance management system in a Malaysian Government Linked Company. Journal of Accounting and Organizational Chang, 5(2), 243-276.

Omar, A.R.C., Mohamad, M.R., Kader, R.A. (2012). Entrepreneurship Orientation and Malaysian State-owned Enterprises: The Management Challenges. Proceedings in 3rd International Conference on Business and Economic Research (ICBER), March 12-13, 2012. Bandung, Indonesia. 
Pallant, J., 2011. SPSS Survival Manual: a Step by Step Guide to Data Analysis Using SPSS, (4th Ed). Australia: Allen \& Unwin.

PCG Secretariat. (2005). Catalysing GLC Transformation to Advance Malaysia's Development. Retrieved from: http://www.pcg.gov.my/PDF/ PCG_Secretariat_29Jul05.pdf.

Rahman, B.A., Shariff, M.N.M. (2009). Knowledge-based Malaysian GLC: Are they more innovative and performing much better? Malaysian Management Journal, 13(1\&2), 11-19.

Ramasamy, B., Ong, D., Yeung, C.H. (2005). Firm size, ownership and performance in the Malaysian palm oil industry. Asian Academy of Management Journal of Accounting and Finance, 1, 81-104.

Razak, N.H.A, Ahmad, R., Joher, H.A. (2008). Ownership Structure and Corporate Performance: a Comparative Analysis of Government Linked and Non-government Linked Companies from Bursa Malaysia. Proceedings in 21st Australasian Finance and Banking Conference, August 24, 2008.

Razak, N.H.A, Ahmad, R., Joher, H.A. (2011). Does government linked companies (GLCs) perform better than Non-GLCs? Evidence from Malaysian listed companies. Journal of Applied Finance \& Banking, 1(1), 213-240.

Ripollés-Meliá, M., Menguzzato-Boulard, M., Sánchez-Peinado, L. (2007). Entrepreneurial orientation and international commitment. Journal of International Entrepreneurship, 5, 65-83.

Sekaran, U., Bougie, R. (2009). Research Methods for Business: a Skill Building Approach, (5th Ed). West Sussex, UK: John Wiley \& Sons.

Soininen, J., Martikainen, M., Puumalainen, K. and Kyläheiko, K. (2012a). Entrepreneurial orientation: Growth and profitability of Finnish smalland medium-sized enterprises. International Journal of Production Economics, 140(2012), 614-621.

Soininen, J., Puumalainen, K., Sjögrén, H. and Syrjä,P. (2012b),The impact of global economic crisis on SMEs: Does entrepreneurial orientation matter? Management Research Review, 35(10), 927-944.

Stevenson, H.H., Jarillo, J.C. (1990). a paradigm of entrepreneurship: Entrepreneurial management. Strategic Management Journal, 11, 17-27.

Sun, Q., Tong, W., Tong, J. (2002). How does government ownership affect firm performance? Evidence from China's privatization experience. Journal of Business Finance Accounting, 29(1/2), 1-28.

The Economist. (2005). The Malay Way of Business Change: An Attempt to Revive Malaysia's Underperforming State-owned Firms. August 18. 2005. Retrieved 10 October 2012 from: http://www.economist.com/ node/4307606. 
Tzokas, N., Carter, S., Kyriazopoulos, P. (2001). Marketing and entrepreneurial orientation in small firms. Enterprise and Innovation Management Studies, 2(1), 19-33.

Wang, C.L. (2008). Entrepreneurial orientation, learning orientation, and firm performance. Entrepreneurship Theory and Practice, July, 635-657.

Wiklund, J., Shepherd, D. (2005). Entrepreneurial orientation and small business performance: a configurational approach. Journal of Business Venturing, 20, 71-91.

Zainol, F.A., Daud, W.N.W. (2011). Indigenous ("Bumiputera") Malay entrepreneurs in Malaysia: Government supports, entrepreneurial orientation and firms performances. International Business and Management, 2(1), 86-99.

\begin{abstract}
Abstrakt (in Polish)
Ludzie bardzo często majq negatywne opinie na temat firm powiqzanych z rzqdem $(G L C)$, co spowodowane jest niezadawalajqca efektywnościq głównych graczy w tej branży. W celu poprawienia efektywności firm państwowych, rzqd Malezji w 2004 roku wdrożył Program Transformacji GLC. Jako iż program dobiega końca, należałoby ocenić efektywność GLC. Nasze badania objęły 153 filie i oddziały firm z grupy G20, a celem było zbadanie wpływu wywieranego przez wymiary orientacji przedsiębiorczej na GLC. Opierajq̨ się na przeprowadzonej analizie wielokrotnej regresji, badania nasze dowiodły, iż innowacyjność (INNO), proaktywność (PROA), podejmowanie ryzyka (RISK), agresywne konkurowanie (COMP) oraz autonomia (AUTO) odnotowały znaczq̨cy pozytywny wpływ na efektywność GLC. Jako takie, wszystkie hipotezy sformułowane podczas naszych badań znalazły potwierdzenie. Wyniki sugerujq, że orientacja przedsiębiorcza nie tylko nadaje się do zastosowania w firmach prywatnych, lecz także w GLC. Dlatego GLC nie powinny być postrzegane jako organizacje publiczne; powinny one wykazywać większq przedsiębiorczość w zarzq̨dzaniu organizacjq, by osiqgnąć lepsze efekty. Ponadto, badanie zweryfikowało, że orientacja przedsiębiorcza jest dobrq determinantq efektów osiqganych przez GLC. Praca kończy się zaleceniami dotyczq̨cymi przyszłych badań.
\end{abstract}

Słowa kluczowe: orientacja przedsiębiorcza, firmy, firmy powiqzane z rzqdem, efektywność. 